\title{
Lymphocyte sensitization to nervous tissues and muscle in patients with the Guillain-Barré syndrome
}

\author{
E. A. CASPARY, S. CURRIE, J. N. WALTON, AND E. J. FIELD \\ From the Medical Research Council, Demyelinating Diseases Unit, Newcastle General Hospital, \\ Newcastle upon Tyne
}

SUMMARY By means of an electrophoretic method lymphocytes from patients with the GuillainBarré syndrome ('acute idiopathic polyneuritis') have been shown to be sensitized to both encephalitogenic factor (EF) and a similar basic protein prepared from human sciatic nerve (SNBP). Sensitization was more marked in the acute stage of the disorder during which there also appeared to be a degree of sensitization to muscle. The results are consistent with the view that lymphocytic infiltration of peripheral nerves in the condition is of pathogenetic significance.

Evidence has accumulated which suggests that lymphocyte-mediated hypersensitivity plays a part in the Guillain-Barré (G-B) syndrome (Asbury, Arnason, and Adams, 1969). In an earlier communication we reported that lymphocytes from patients with this disorder were stimulated on culture with basic protein derived from human sciatic nerve (SNBP) and that the phenomenon persisted long after clinical resolution of the syndrome (Knowles, Saunders, Currie, Walton, and Field, 1969). This paralleled the persistence of lymphocytic infiltration in peripheral nerves for years after the acute syndrome (Asbury et al., 1969). No stimulation occurred on incubation with similar basic protein (encephalitogenic factor (EF) derived from central nervous tissue. The technique, which depends upon prolonged survival of lymphocytes in culture, presents several pitfalls which, despite the widespread use of the method, have only now been systematically studied (Hughes and Caspary, 1970). A more reliable and sensitive method has now been developed (Caspary and Field, 1970); it depends upon electrophoretic slowing of guinea-pig macrophages in the presence of lymphocytes which have been stimulated by incubation with a specific antigen. This method has now been applied to the study of lymphocytes from patients with G-B syndrome including some of those featured in the earlier communication (Knowles et al., 1969).

\section{MATERIALS AND METHODS}

There were sixteen patients with the G-B syndrome. Some clinical features of these cases are given in Table 1. The mean period over which the syndrome had evolved from onset to the point of maximum deficit was two weeks. Infection, usually respiratory, preceded the disorder in 10 patients. Other antecedent factors were surgery, the puerperium, and neoplasia, each in a single case. The amount of protein in the cerebrospinal fluid was increased in 12 out of the 15 patients in whom an estimation was made. A demyelinating neuropathy was suggested by a marked reduction in motor nerve conduction velocity in 10 of the 14 patients in whom neurophysiological studies were carried out. Sural nerve biopsy was performed in three patients and showed segmental demyelination. Steroid therapy (ACTH or prednisone) was followed by improvement in the eight patients so treated. Only one (no. 11) was receiving prednisone when blood was taken for testing. In five patients (nos. 1 to 5) the lymphocytes were studied during the acute stage of the syndrome. One of these (no. 2) was suffering from his third relapse in 25 years. Muscular atrophy was apparent in all five cases. In the remaining 11 patients the disorder had occurred between 0.6 and 4.5 years before the sampling of blood, with a mean interval of 1.9 years. In seven patients a deficit remained which was static in two and resolving in the other five. However, no neurogenic atrophy was noted in any of these 11 patients at the time of study.

BLOOD LYMPHOCYTES Lymphocytes were prepared from defibrinated venous blood by removal of polymorphs with saccharated iron and sedimentation with methyl cellulose (Hughes and Caspary, 1970). This gave a yield of about $10^{6}$ lymphocytes $/ \mathrm{ml}$. blood.

GUINEA-PIG MACROPHAGES A macrophage rich exudate was obtained from guinea-pig peritoneal cavity by wash- 
TABLE 1

CLINICAL FEATURES OF PATIENTS WITH GUILLAIN-BARRÉ SYNDROME: LYMPHOCYTE SENSITIZATION TO CENTRAL AND PERIPHERAL NERVOUS TISSUE AND MUSCLE IN THESE PATIENTS AND CONTROL SUBJECTS

\begin{tabular}{|c|c|c|c|c|c|c|c|c|c|c|}
\hline \multirow[t]{2}{*}{ Patient No. } & \multirow[t]{2}{*}{$\begin{array}{l}\text { Age } \\
(y r)\end{array}$} & \multirow[t]{2}{*}{$\operatorname{Sex}$} & \multirow[t]{2}{*}{ Antecedent factors } & \multirow{2}{*}{$\begin{array}{c}C S F \\
\text { protein } \\
(m g / 100 \mathrm{ml} .)\end{array}$} & \multirow{2}{*}{$\begin{array}{l}\text { Significant } \\
\text { reduction in } \\
\text { motor nerve } \\
\text { conduction } \\
\text { velocity }\end{array}$} & \multirow{2}{*}{$\begin{array}{l}\text { Apparent } \\
\text { clinical } \\
\text { response } \\
\text { to steroid } \\
\text { therapy }\end{array}$} & \multirow{2}{*}{$\begin{array}{c}\text { Interval (yr) } \\
\text { between onset } \\
\text { of illness } \\
\text { and testing } \\
\text { of lymphocytes }\end{array}$} & \multicolumn{3}{|c|}{ 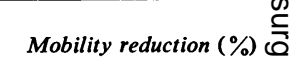 } \\
\hline & & & & & & & & $S N B P$ & $E F$ & 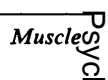 \\
\hline \multicolumn{11}{|l|}{ In acute stage } \\
\hline 1 & 41 & $\mathbf{F}$ & Infection & 82 & Not tested & + & 0 & $21 \cdot 0$ & $21 \cdot 8$ & $17 \cdot 7$ 完 \\
\hline 2 & 68 & $\mathbf{M}$ & - & 210 & + & + & $\begin{array}{c}0 \\
\text { (relapsing) }\end{array}$ & $27 \cdot 6$ & $20 \cdot 5$ & $12 \cdot 9=$ \\
\hline 3 & 44 & $\mathbf{M}$ & Infection & 96 & + & Not given & 0 & $24 \cdot 5$ & $20 \cdot 1$ & $26.0 \stackrel{0}{\longrightarrow}$ \\
\hline 4 & 23 & $\mathbf{F}$ & Infection & 116 & - & + & 0 & 23.9 & $23 \cdot 3$ & $7.8 \overline{0}$ \\
\hline 5 & 55 & $\mathbf{M}$ & Infection & 250 & + & + & $\mathbf{0}$ & $19 \cdot 9$ & $23 \cdot 5$ & $2 \cdot 4 \frac{\bar{\sigma}}{\sigma}$ \\
\hline \multicolumn{11}{|l|}{ After resolution } \\
\hline 6 & 70 & $\mathbf{M}$ & Surgery & 28 & + & Not given & $3 \cdot 0$ & $16 \cdot 7$ & $16 \cdot 4$ & $2.0 \vec{\nabla}$ \\
\hline 7 & 28 & $\mathbf{F}$ & Puerperium & 28 & + & Not given & $2 \cdot 0$ & $14 \cdot 2$ & 14.9 & $2 \cdot 1$ 르 \\
\hline 8 & 53 & $\mathbf{F}$ & Infection & 151 & + & + & $1 \cdot 0$ & $11 \cdot 2$ & $13 \cdot 8$ & -0.3 บิ \\
\hline 9 & 50 & $\mathbf{F}$ & Infection & 84 & + & Not given & $1 \cdot 2$ & $13 \cdot 4$ & $16 \cdot 3$ & $-0.5 \omega$ \\
\hline 10 & 64 & $\mathbf{F}$ & Infection & 38 & + & + & 0.6 & $10 \cdot 2$ & $9 \cdot 4$ & -1.6 \\
\hline 11 & 45 & $\mathbf{M}$ & - & 38 & + & Not given & 0.6 & $15 \cdot 7$ & $14 \cdot 5$ & 0.6 \\
\hline 12 & 42 & $\mathbf{F}$ & Infection & 60 & - & Not given & $2 \cdot 2$ & $18 \cdot 8$ & $16 \cdot 2$ & 0.1 二 \\
\hline 13 & 37 & $\mathbf{M}$ & Infection & 250 & + & + & $4 \cdot 5$ & $16 \cdot 8$ & $16 \cdot 0$ & $0 \bar{\omega}$ \\
\hline 14 & 54 & $\mathbf{M}$ & Infection & 157 & Not tested & Not given & $3 \cdot 5$ & $15 \cdot 4$ & $13 \cdot 2$ & $6.3 \stackrel{\Omega}{\Omega}$ \\
\hline 15 & 45 & $\mathbf{M}$ & Thymoma & 220 & - & + & $1 \cdot 5$ & $13 \cdot 2$ & 13.9 & $0 \supseteq$ \\
\hline 16 & 42 & $\mathbf{F}$ & - & 128 & - & Not given & 0.7 & 10.4 & $11 \cdot 7$ & -0.3 귱 \\
\hline \multicolumn{8}{|c|}{10 control subjects $20-55,5 \mathrm{M}, 5 \mathrm{~F}$} & \multicolumn{3}{|c|}{$(3 \cdot 7-1 \cdot 1)(8 \cdot 5-0.9)(2 \cdot 2-1 \cdot 0 \dot{\omega}$} \\
\hline
\end{tabular}

ing out with heparinized Hanks' solution $(5 \mathrm{u} / \mathrm{ml}$.) eight to 12 days after injection of $20 \mathrm{ml}$. sterile liquid paraffin. The exudate was washed in heparinized Hanks' solution, then in Hanks' solution without heparin (250 $\mathrm{g}$ for 10 minutes), and finally suspended in $10 \mathrm{ml}$. of medium 199. The cells were counted and the volume adjusted to give $10^{7}$ macrophages $/ \mathrm{ml}$. This macrophage suspension (containing 10 to $20 \%$ of lymphocytes) was irradiated with $100 \mathrm{r}$ (cobalt $60 \gamma$ rays) in order to eliminate reactivity of contaminating lymphocytes and so obviate a 'mixed lymphocyte' reaction.

ANTILYMPHOCYTIC SERUM The rabbit anti-guinea-pig lymphocyte serum which was used was that previously shown to afford marked protection against the development of experimental allergic encephalomyelitis (Field, 1969), and to block antigen/lymphocyte interaction (Field, Caspary, Hall, and Clark, 1970). Agglutination titre of this serum was $1: 1200$.

ENCEPHALITOGENIC FACTOR (EF) The encephalitogenic factor which was used was prepared from fresh young human brain (subject blood group $\mathrm{O}$ ) (Caspary and Field, 1965).

BASIC PROTEIN FROM PERIPHERAL NERVE (BP) Basic protein from human sciatic nerve was prepared in the same way as EF. It was weakly neuritogenic in guineapigs when used with the same proportion of Freund's adjuvant as served to produce encephalitis when given with EF (but it is possible that different proportions of adjuvant and concentrations of BP might show a higher pathogenicity).
MUSCLE Human erector spinae muscle $(20 \% \mathrm{w} / \mathrm{v})$ aQ homogenized in saline and centrifuged at $250 \mathrm{~g}$ for 10 minutes. The supernatant fluid was used as musclo antigen.

PROCEDURE The tests for sensitization of periphaitiat lymphocytes were carried out as follows. $10 \times 70^{\circ}$ irradiated guinea-pig macrophages in TC 199 were mixe with $0.5 \times 10^{6}$ human peripheral lymphocytes and the total volume made up to $3 \mathrm{ml}$. with TC 199. Antigen in $0.1 \mathrm{ml}$. volume (EF $100 \mu \mathrm{g}$; BP $100 \mu \mathrm{g}$; Muscle supernat from $20 \%(w / v))$ was added and the mixture incubate $\$$ at room temperature for 90 minutes before the electro phoretic mobility was measured.

ELECTROPHORETIC MEASUREMENTS Electrophoretic mobilit was measured in a Zeiss cytopherometer. Each speck men was gently agitated and examined for cell as gregation before introduction into the cytopheromete्2 chamber which was maintained at a temperature of $23^{\circ} \mathrm{C} \pm 0.05^{\circ} \mathrm{C}$. Observations were restricted to macro phages, readily recognizable by their size and liquid paraffin content under phase contrast illumination. The migration time of 10 cells was measured to the nearest 0.1 second, each in both directions of the potentia difference $(180 \mathrm{~V}$ at $7.5 \mathrm{~mA})$ and average values derived from 20 readings were calculated. Changes in migratio time were expressed as a percentage of the control time that is, that of macrophages in the presence of the humaqP blood cells under test without addition of antigen. Avb measurements were made 'blind', the results being lat uncoded. 


\section{RESULTS}

Table 1 shows sensitization of peripheral lymphocytes to antigens of both central and peripheral nervous origin $(P<0.001)$ in the G-B syndrome when compared with control subjects. There was a significant difference between cases in the acute stage and those after recovery in the response to EF $(P<0.001)$ and to SNBP $(P<0.001)$. Acute cases also showed a response to muscle not shown in those who had recovered $(P<0.001)$. However, the number of acute cases was small and these findings must be treated with caution. In the cases after recovery there was no correlation with the time which had elapsed since the acute syndrome.

The response to all three antigens was abolished by ALS (Table 2) confirming the immune nature of the reaction (Field, Hughes, and Caspary, 1969).

TABLE 2

EFFECT OF ANTI-LYMPHOCYTIC SERƯM (RABBIT ANTIGUINEA PIG LYMPHOCYTES) ON LYMPHOCYTE SENSITIZATION IN VITRO OF CELLS FROM PATIENTS WITH GUILLAIN-BARRÉ SYNDROME

\begin{tabular}{lcc}
\hline \multicolumn{1}{c}{ Antigen } & \multicolumn{2}{c}{ Mobility reduction $(\%)$} \\
\hline EF & $20 \cdot 5(2)$ & $13 \cdot 8(8)$ \\
ALS + EF & 1.0 & $0 \cdot 3$ \\
SNBP & $27.6(2)$ & $13.4(9)$ \\
ALS + SNBP & 1.3 & 1.5 \\
Muscle & $12.9(2)$ & $17 \cdot 7(1)$ \\
ALS + Muscle & 0.1 & 3.4 \\
\hline
\end{tabular}

Figures in parentheses refer to patients in Table 1.

\section{DISCUSSION}

The results suggest that lymphocytes from patients with the G-B syndrome are sensitized to protein of both central and peripheral neural origin. The response to central protein is not surprising, since infiltrates of mononuclear cells and destructive changes are known to occur within the central as well as in the peripheral nervous system (Schmaus, 1904), though such changes are rarely prominent or of clinical significance (Haymaker and Kernohan, 1949). Failure to find stimulation by EF in our pre- vious work (Knowles et al., 1969) probably resulted from the relative insensitivity of the method and the technical vagaries to which it is subject (Hughes and Caspary, 1970). However, Behan, Lamarche, Feldman, Behan, and Kies (1969) did record stimulation with central protein, though in their cases a response to either central or peripheral protein did not persist after resolution of the clinical syndrome. In the present cases sensitization persisted long after recovery, though reduced in degree. In the active phase, during which denervation atrophy was progressing, lymphocytes which were sensitized to muscle antigen were also present, though not subsequently. The apparent sensitization to muscle was probably a secondary phenomenon and illustrates once again the difficulty in deducing a pathogenetic role from findings of antibodies and cellular sensitization in 'autoimmune' disorders.

\section{REFERENCES}

Asbury, A. K., Arnason, B. G., and Adams, R. D. (1969). The inflammatory lesion in idiopathic polyneuritis. Its role in pathogenesis. Medicine (Baltimore), 48, 173-215.

Behan, P. O., Lamarche, J. B., Behan, M. W., Feldman, R. G., and Kies, M. W. (1969). Immunopathological mechanisms of allergic neuritis in animals, primates, and man. Trans. Amer. neurol. Ass., 94, 219-231.

Caspary, E. A., and Field, E. J. (1970). Demonstration of sensitised lymphocytes in blood. J. clin. Path. (In press.)

Caspary, E. A., and Field, E. J. (1965). An encephalitogenic protein of human origin, some chemical and biological properties. Ann. N. Y. Acad. Sci., 122, 182-198.

Field, E. J. (1969). Antilymphocytic serum in experimental allergic encephalomyelitis. Brit. med. J., 3, 758-760.

Field, E. J., Caspary, E. A., Hall, R., and Clark, F. (1970). Circulating sensitised lymphocytes in Graves' disease. Lancet, 1, 1144-1147.

Field, E. J., Hughes, D., Caspary, E. A. (1969). Mode of action of antilymphocytic serum. Lancet, 2, 964.

Haymaker, W., and Kernohan, J. W. (1949). The LandryGuillain-Barré syndrome. A clinicopathologic report of fifty fatal cases and a critique of the literature. Medicine (Baltimore), 28, 59-141.

Hughes, D., and Caspary, E. A. (1970). Lymphocyte transformation in vitro measured by tritiated thymidine uptake. Int. Arch. Allergy, 37, 506-531.

Knowles, M., Saunders, M., Currie, S., Walton, J. N., and Field, E. J. (1969). Lymphocyte transformation in the Guillain-Barré syndrome. Lancet, 2, 1168-1170.

Schmaus, H. (1904). Die Landry 'schen Paralyse. Ergebn. allg. Path. path. Anat., 1, 396-409. 